\title{
CONSERVATION DEVELOPMENT OF TIMOR DEER (Cervus timorensis) AS COMMERCIAL PURPOSE(WITH OPTIMISTIC RATE ESTIMATION)
}

\author{
S.I. Santoso ${ }^{1}$, Z. Fanani ${ }^{2}$, B. A. Nugroho ${ }^{2}$ and N. Hanani ${ }^{2}$ \\ ${ }^{1}$ Faculty of Animal Agriculture, Diponegoro University \\ Tembalang Campus, Semarang 50275, Central Java - Indonesia \\ ${ }^{2}$ Faculty of Animal Science Brawijaya University \\ Jl Mayor Jendral Haryono 169, Malang 65144, East Java - Indonesia. \\ Corresponding E-mail: sisdaris2005@yahoo.com
}

Received February 09, 2012; Accepted July 16, 2012

\begin{abstract}
ABSTRAK
Tujuan penelitian ini adalah menentukan keuntungan yang didapatkan dari budidaya rusa Timor secara komersial. Penelitian dilakukan di Jawa Timur dengan metode survey. Lokasi penelitian ditentukan dengan metode purposive sampling. Biasanya rusa dikembangkan di lokasi konservasi, tetapi dikarenakan luas area konservasi yang semakin berkurang menyebabkan jumlah rusa juga berkurang. Model pengembangan rusa seharusnya tidak hanya sebagai konservasi tetapi dengan tujuan komersial. Budidaya rusa yang optimum dipertimbangkan dan dimonitor dengan tujuan memaksimumkan rusa timor dengan menggunakan Multiple Objective Goal Programming (MGOP) untuk menemukan estimasi rata-rata yang paling optimal. Hasil menunjukkan bahwa untuk mendapatkan keuntungan yang optimal, budidaya rusa sebagai hewan konservasi dan komersial perlu dilaksanakan dalam waktu yang sama. Hasil keuntungan yang didapatkan dari penjualan ranggah sebesar $164,46 \%$, penjualan tanduk $350,56 \%$, penjualan rusa hidup $394,28 \%$, penjualan tiket rekreasi $259,08 \%$, penjualan daging rusa $135,98 \%$ dan penjualan kulit $141,24 \%$. Biaya operasional yang dikeluarkan yaitu biaya pakan $168,46 \%$, biaya pemeliharaan sebesar 213,23\%, dan biaya tenaga kerja sebesar 232,04\%. Biaya yang dibutuhkan untuk MGOP model biaya pakan $185,54 \%$, biaya pemeliharaan sebesar $253,13 \%$, dan biaya tenaga kerja sebesar 246,95\%. Keuntungan yang didapatkan dengan pertimbangan komersial sebesar 335,21 sedangkan model MOGP dengan biaya yang lebih murah akan mendapatkan keuntungan sampai dengan $381,26 \%$ bagi pengelola.
\end{abstract}

Kata kunci: rusa Timor, konservasi, komersial, metode optimum

\begin{abstract}
The aim of this research was to determine the profit obtained from breeding of Timor deer commercially. This research was done in East Java. Survey method was used to answer the objective. The study location were selected by purposive sampling. Usually deer was develop in conservation area, but because the area was decrease so the number of deer also decrease. Model of deer raising development should be improved not only for conservation but also for commercial purpose. The optimum deer raising were considered and monitored with a purpose to maximize commercial Timor deer by using Multiple Objective Goal Programming (MOGP) to find the Optimistic Rate Estimation. The result of this study showed to get the optimum benefit, it had to be applied together with conservation and commercial effort at the same time. Results of study showed that profit was taken from selling velvet was $164.46 \%$. Profits taken from selling antler was $350.56 \%$, from selling alive deer was $394.28 \%$, from selling recreation tickets was $259.08 \%$, from selling venison 1 was $135.98 \%$, and from selling deer leather was $141.24 \%$. Operational cost spent were $168.46 \%$ for feeding cost, $213.23 \%$ for maintenance cost, and $232.04 \%$ for labors' salaries. The amount of operational cost required in MOGP model, with lower expenses and commercial priority were $185.54 \%$ for feeding cost, $253.13 \%$ for maintenance cost, and $246.95 \%$ for paying labors' salaries. The MOGP model result with commercial priority reached $335.21 \%$, while in MOGP model with lower costs and commercial priority gave profit for breeders up to $381.26 \%$.
\end{abstract}

Keywords: Timor deer, conservation, commercial , optimum method 


\section{INTRODUCTION}

Timor deer (Cervus timorensis) is an endemic animal in Indonesia. Indonesia have tropical climate which is capable for Timor deer to survive (Semiadi and Nugraha, 2004). Cultivated deer also has benefit for human like cattle, Deer can be produce meat, velvet, and skin which use by human (Garsetiasih, 2000). With those advantages, it is necessary to breed Timor deer to get profit, the previous study began to look for the technical coefficient of Timor deer for conservation and commercial purpose (Santoso et al., 2006).

As stated in Indonesian law and the government regulation, Timor deer were prohibited to be caught in first and second generation, however starting from the third generation they could be cultivated as commercial purpose. The major products expected are meat production and its by product such as velvet that could be used as medicine material which has high economic value (Jamal et al., 2005). Breeding of deer is interesting because of several advantages (Dradjat, 2002; Schuhmann and Schwabe, 2000: Semiadi and Nugraha, 2004). Deer meat, which is called as venison, is popular because it contains low cholesterol and fat. Compared to beef, the venison cholesterol and fat was lower, beside that venison is soft and has low-calorie content (Puttoo, 1998). Based on those reasons, the aims of the study were to determine the benefit of deer raising for conservation as well as commercial purpose through MGOP.

\section{MATERIALS AND METHODS}

\section{Research Design and Collection Data}

Survey method were used in the study. Four Timor deer breeding and conservation locations in Blitar Jatilangger Tourism Place, Surabaya Zoo, Safari Park II of Prigen Pasuruan, and Coban Rondo Tourism Place in Batu Malang were used in this study. These locations were determined by purposive sampling method. The locations were considered as study area because all of the places has more than 30 heads of deer. The scope of study was to involve the investment spent in breeding Timor deer, working capital, operational cost, and profit from breeding yield, and the technical data of economic evaluation every deer which cultivated in 18 months.

\section{Statistical Analysis}

To obtain optimum solution in cultivating timor deer, it is necessarily considered the available support and maintained the development to conservation purpose. Thus, it is required an effort as the consideration for maximizing Timor deer commercial development by implementing Multiple Objective Goal Programming (MOGP). The MOGP has function to maximize social benefit to obtain societal optimum. MOGP is very useful to establish the analysis of determining resource requirements to reach purposes with the available resources (Chuang and Lu, 1997). Meanwhile, it will give a satisfying resolution regarding on various inputs, aspiration levels, and priority arrangement (Soekartawi, 1995).

\section{RESULTS AND DISCUSSION}

The new regulation stated that developing deer is not being restricted. The commercial deer could be further developed starting from third generation, because the development has benefit not only for conservation but also for commercial purpose. This model was proved to reserve the deer population (Fatem, 2002).

The development of MOGP model scenario by using Optimistic Rate Estimation for cultivating this Timor deer should be followed the ratio $1: 3$ to conservation and commercial purpose in four breeding locations. According to the data in the four breeding locations, it showed $7 \mathrm{Ha}$ land in Blitar Jatilangger Tourism Place were optimally used, 20 heads of deer can be optimally cultivated to 140 heads, and 60 head of commercial deer can be optimally cultivated to 420 heads. While in Surabaya Zoo, 2 Ha land can be optimally used, 75 heads of deer will be optimally cultivated to 150 heads, and 225 heads deer will be optimally cultivated to 560 heads. In Safari Park II of Prigen Pasuruan, $15 \mathrm{Ha}$ land could be optimally used, 20 heads of deer will be optimally cultivated to 300 heads, and 60 heads of commercial one will be optimally cultivated to 600 heads. Whereas in Coban Rondo Tourism Place of Pujon Malang, $4 \mathrm{Ha}$ land could be optimally used, 20 heads of deer could be optimally cultivated to 80 heads, and 60 heads of commercial one can be optimally cultivated to 240 heads.

Based on MOGP scenario result to develop Timor deer in East Java with the major priority on commercial purpose in four breeding locations 
with lower expenses, the findings showed that commercial purpose obtained huge profit. The amount of profit in MOGP model with the commercial priority in four breeding locations could be described as follows: $164.75 \%$ from selling velvet, $313.66 \%$ from selling antler, $358.15 \%$ from selling alive deer, $93.94 \%$ from selling recreation tickets, $137.55 \%$ from selling venison, and $141.46 \%$ from selling deer leather which can be reached by deer breeders in 18 months period.

Results of study showed the amount of profit were taken based on MOGP model with lower expenses and commercial priority could be described as follows: profit was taken from selling velvet, selling antler, selling alive deer, selling recreation tickets, selling venison and selling deer leather was $164.46 \%, 350.56 \%$, $394.28 \%$, 259.08\%, $135.98 \%$, and $141.24 \%$, respectively. The deer was cultivated in 18 months period.

Operational cost spent in four breeding locations were $168.46 \%$ for feeding cost, $213.23 \%$ for maintenance cost, and $232.04 \%$ for labors' salaries in 18 months period. Furthermore the amount of operational cost required in MOGP model, with lower expenses and commercial priority in four breeding locations could be described as follows: $185.54 \%$ for feeding cost, $253.13 \%$ for maintenance cost, and $246.95 \%$ for paying labors' salaries in 18 months period.

The net profit estimation received by breeders as the MOGP model result with commercial priority in four breeding locations reached $335.21 \%$, while in MOGP model with lower costs and commercial priority in four breeding locations might give profit for breeders up to $381.26 \%$. As shown as in Table 1, the application of MOGP model was estimated to give more profit for breeders after 1.5 years developing deer, both conservative and commercial affairs. As for the average amount of profit reached from deer cultivated more than $100 \%$ from the expected objectives compared to tourism purpose only (Table 2).

MOGP showed that there were not many objectives yet reached as it was expected, but the other objectives were reached and gave huge profit for breeders who cultivate Timor deer, especially in East Java. Even with MOGP scenario model with commercial priorities in four breeding locations, especially MOGP model with lower expenses and commercial priorities in four breeding locations may give net profit up to more than 300 per cents. It showed that the conservation and commercial deer developments by using MOGP scenario model, although they need operational costs more than the available fund budget, were estimated to give higher profit than the other scenario models for 18 months of harvesting period.

Similar to the above MOGP model, the deer development on these two MOGP models, by commercial priorities in four breeding locations and lower expenses and commercial priorities could be conducted for multi-functions, that was the combination of conservation and commercial efforts. The previous scenarios showed that the current breeding Timor deer only had conservation purpose and gained less optimum profit for breeders, therefore, it was necessary to develop it commercially to gain optimal profit (Santoso et al., 2005). Thus, it was expected that developing Timor deer, both in conservative and commercial ways, would run at the same time, though in different percentage. In conservation purpose, deer, especially Timor deer would experience destruction since the conservation purpose refers to a method to conserve wildlife, particularly population that was almost destroyed (Garsetiasih, 2000; Bromley and Gese, 2001).

In commercial way, to develop Timor deer is a method to gain greater benefit from some potential deer commodities to public market. Besides, the results of this multi-function would give financial benefit and larger economic benefit, such as recruiting from society, recreation, profits from selling potential deer commodities such as velvet, venison, live deer, leather, and so on. Even the advantages of these two MOGP models insert the possibility to develop deer for commercial purpose which might give profit in recreation tickets as in conservation affair. Therefore, the profit for breeders was estimated larger.

Result of the study showed that commercial deer development in the full MOGP models found larger land and expenditures needed than area for conservative deer development only. The commercial Timor deer development resulted more deer numbers than conservation. Production of Timor deer through commercialization would resulted higher income compare with conservation only (Bromley and Gese, 2001). Thus, to expand the areas for deer raising, it 
Table 1. Model of MGOP in Usual Activity in 4 Locations of Study

\begin{tabular}{|c|c|c|c|c|c|c|c|c|c|}
\hline Description & $\begin{array}{l}\text { Conserv. - } \\
\text { Surabaya }\end{array}$ & $\begin{array}{l}\text { Commercial - } \\
\text { Surabaya }\end{array}$ & $\begin{array}{l}\text { Conserv. } \\
\text { Prigen }\end{array}$ & $\begin{array}{l}\text { Commercial - } \\
\text { Prigen }\end{array}$ & $\begin{array}{c}\text { Conserv.- } \\
\text { Blitar }\end{array}$ & $\begin{array}{c}\text { Commercial - } \\
\text { Blitar }\end{array}$ & $\begin{array}{c}\text { Conserv. } \\
\text { - Batu }\end{array}$ & $\begin{array}{c}\text { Commercial } \\
\text { - Batu }\end{array}$ & Total \\
\hline \multicolumn{10}{|c|}{ Profit from Sales: } \\
\hline $\begin{array}{l}\text { Profit from } \\
\text { velvet }\end{array}$ & 0 & $2,394,130$ & 0 & $1,935,867$ & - & $1,873,850$ & - & 420,401 & $6,624,248$ \\
\hline $\begin{array}{l}\text { Profit from } \\
\text { antler }\end{array}$ & 9,139 & 718,239 & $2,025,990$ & $2,419,834$ & - & 851,750 & - & 150,143 & $6,175,096$ \\
\hline $\begin{array}{l}\text { Profit from } \\
\text { alive cattle }\end{array}$ & 182,784 & $28,729,560$ & $47,002,968$ & $72,595,035$ & - & $15,331,500$ & - & $2,252,149$ & $166,093,997$ \\
\hline Tickets income & $3,459,500$ & - & $400,867,649$ & $17,422,808$ & - & $15,331,500$ & - & 120,114 & $437,201,572$ \\
\hline Meat income & - & $12,569,182$ & - & $33,006,542$ & - & $5,110,500$ & - & $3,153,009$ & $53,839,234$ \\
\hline Leather income & - & 861,886 & - & 871,140 & - & 511,050 & - & 90,086 & $2,334,163$ \\
\hline Total income & & & & & & & & & $672,268,312$ \\
\hline \multicolumn{10}{|l|}{ Side-purpose: } \\
\hline $\begin{array}{l}\text { Employing } \\
\text { labors }\end{array}$ & 0 & 2 & 4 & 3 & 0 & 2 & 0 & 1 & 12 \\
\hline \multicolumn{10}{|c|}{ Numbers of Deer/Ha } \\
\hline $\begin{array}{l}\text { Surabaya } \\
\text { Conservation } \\
\text { Area }\end{array}$ & 0.9 & 0 & 0 & 0 & 0 & 0 & 0 & 0 & 0.9 \\
\hline $\begin{array}{l}\text { Surabaya } \\
\text { Commercial } \\
\text { Area }\end{array}$ & 0 & 107.7 & 0 & 0 & 0 & 0 & 0 & 0 & 107 \\
\hline Surabaya Area & 0.9 & 107.7 & 0 & 0 & 0 & 0 & 0 & 0 & 103.6 \\
\hline $\begin{array}{l}\text { Prigen } \\
\text { Conservation } \\
\text { Area }\end{array}$ & 0 & 0 & 27.0 & 0 & 0 & 0 & 0 & 0 & 27.0 \\
\hline $\begin{array}{l}\text { Prigen } \\
\text { Commercial } \\
\text { Area }\end{array}$ & 0 & 0 & 0 & 29.0 & 0 & 0 & 0 & 0 & 29.0 \\
\hline Prigen Area & 0 & 0 & 27.0 & 29.0 & 0 & 0 & 0 & 0 & 56.1 \\
\hline $\begin{array}{l}\text { Blitar } \\
\text { Conservation } \\
\text { Are }\end{array}$ & 0 & 0 & 0 & 0 & 0 & 0 & 0 & 0 & 0 \\
\hline $\begin{array}{l}\text { Blitar } \\
\text { Commercial } \\
\text { Area }\end{array}$ & 0 & 0 & 0 & 0 & 0 & 20.4 & 0 & 0 & 20.4 \\
\hline Blitar Area & 0 & 0 & 0 & 0 & 0 & 20.4 & 0 & 0 & 20.4 \\
\hline $\begin{array}{l}\text { Batu } \\
\text { Conservation } \\
\text { Area }\end{array}$ & 0 & 0 & 0 & 0 & 0 & 0 & 0 & 0 & 0 \\
\hline $\begin{array}{l}\text { Batu } \\
\text { Commercial } \\
\text { Area }\end{array}$ & 0 & 0 & 0 & 0 & 0 & 0 & 0 & 3.6 & 3.6 \\
\hline Batu Area & 0 & 0 & 0 & 0 & 0 & 0 & 0 & 3.6 & 3.6 \\
\hline Total & 1.8 & 215.5 & 54 & 58.1 & 0 & 40.9 & 0 & 7.2 & 377.5 \\
\hline \multicolumn{10}{|c|}{ Operational Cost: } \\
\hline Feeding cost & 182,784 & $10,773,585$ & $10,643,127$ & $7,755,477$ & - & $7,665,750$ & - & 945,902 & $37,957,627$ \\
\hline Labor cost & 175,437 & $13,790,188$ & $33,860,370$ & $9,437,354$ & - & $6,132,600$ & - & 900,860 & $64,296,847$ \\
\hline $\begin{array}{l}\text { Maintenance } \\
\text { cost }\end{array}$ & 91,392 & $7,182,390$ & $14,181,930$ & $18,133,368$ & - & $11,866,857$ & - & 758,163 & $52,214,101$ \\
\hline $\begin{array}{l}\text { Total } \\
\text { Expenditures }\end{array}$ & & & & & & & & & $154,468,575$ \\
\hline Balance & & & & & & & & & $517,799,736$ \\
\hline
\end{tabular}


Table 2. Model MGOP to Maximize the Profit in 4 Locations of Study

\begin{tabular}{|c|c|c|c|c|c|c|c|c|c|}
\hline Description & $\begin{array}{l}\text { Conserv. - } \\
\text { Surabaya }\end{array}$ & $\begin{array}{l}\text { Commercial } \\
\text { - Surabaya }\end{array}$ & $\begin{array}{l}\text { Conserv. } \\
\text { Prigen }\end{array}$ & $\begin{array}{c}\text { Commercial - } \\
\text { Prigen }\end{array}$ & $\begin{array}{l}\text { Conserv. } \\
\text { Blitar }\end{array}$ & $\begin{array}{c}\text { - Commercial - } \\
\text { Blitar }\end{array}$ & $\begin{array}{l}\text { Conserv. - C } \\
\text { Batu }\end{array}$ & $\begin{array}{c}\text { Commercial } \\
\text { - Batu }\end{array}$ & Total \\
\hline \multicolumn{10}{|c|}{ Profit from Sales: } \\
\hline $\begin{array}{l}\text { Profit from } \\
\text { velvet }\end{array}$ & - & $2,398,500$ & - & $1,915,200$ & - & $1,936,000$ & 3,200 & 359,800 & $6,612,700$ \\
\hline $\begin{array}{l}\text { Profit from } \\
\text { antler }\end{array}$ & - & 719,550 & $2,778,450$ & $2,394,000$ & - & 880,000 & 1,200 & 128,500 & $6,901,700$ \\
\hline $\begin{array}{l}\text { Profit from } \\
\text { alive cattle }\end{array}$ & - & $28,782,000$ & $64,460,040$ & $71,820,000$ & - & $15,840,000$ & 18,000 & $1,927,500$ & $182,847,540$ \\
\hline Tickets income & - & 479,700 & $550,133,100$ & $17,236,800$ & - & $15,840,000$ & 244,200 & 120,800 & $584,036,600$ \\
\hline Meat income & - & $12,592,125$ & - & $32,654,160$ & - & $5,280,000$ & - & $2,698,500$ & $53,224,785$ \\
\hline $\begin{array}{l}\text { Leather } \\
\text { income }\end{array}$ & - & 863,460 & - & 861,840 & - & 528,000 & - & 77,100 & $2,330,400$ \\
\hline Total income & & & & & & & & & $835,953,725$ \\
\hline \multicolumn{10}{|l|}{ Side-purpose: } \\
\hline $\begin{array}{l}\text { Employing } \\
\text { labors }\end{array}$ & 0 & 2 & 7 & 3 & 0 & 2 & 0 & 1 & 15 \\
\hline \multicolumn{10}{|c|}{ Numbers of Deer/Ha : } \\
\hline $\begin{array}{l}\text { Surabaya } \\
\text { Conservation } \\
\text { Area }\end{array}$ & 0.9 & 0 & 0 & 0 & 0 & 0 & 0 & 0 & 0.9 \\
\hline $\begin{array}{l}\text { Surabaya } \\
\text { Commercial } \\
\text { Area }\end{array}$ & 0 & 107.9 & 0 & 0 & 0 & 0 & 0 & 0 & 107.9 \\
\hline Surabaya Area & 0 & 107.9 & 0 & 0 & 0 & 0 & 0 & 0 & 107.9 \\
\hline $\begin{array}{l}\text { Prigen } \\
\text { Conservation } \\
\text { Area }\end{array}$ & 0 & 0 & 37.0 & 0 & 0 & 0 & 0 & 0 & 37.0 \\
\hline $\begin{array}{l}\text { Prigen } \\
\text { Commercial } \\
\text { Area }\end{array}$ & 0 & 0 & 0 & 28.7 & 0 & 0 & 0 & 0 & 28.7 \\
\hline Prigen Area & 0 & 0 & 37.0 & 28.7 & 0 & 0 & 0 & 0 & 65.8 \\
\hline $\begin{array}{l}\text { Blitar } \\
\text { Conservation } \\
\text { Are }\end{array}$ & 0 & 0 & 0 & 0 & 0 & 0 & 0 & 0 & 0 \\
\hline $\begin{array}{l}\text { Blitar } \\
\text { Commercial } \\
\text { Area }\end{array}$ & 0 & 0 & 0 & 0 & 0 & 21.1 & 0 & 0 & 21.1 \\
\hline Blitar Area & 0 & 0 & 0 & 0 & 0 & 21.1 & 0 & 0 & 21.1 \\
\hline $\begin{array}{l}\text { Batu } \\
\text { Conservation } \\
\text { Area }\end{array}$ & 0 & 0 & 0 & 0 & 0 & 0 & 0 & 0 & 0 \\
\hline $\begin{array}{l}\text { Batu } \\
\text { Commercial } \\
\text { Area }\end{array}$ & 0 & 0 & 0 & 0 & 0 & 0 & 0 & 3.1 & 3.6 \\
\hline Batu Area & 0 & 0 & 0 & 0 & 0 & 0 & 0 & 3.1 & 3.6 \\
\hline Total & 0 & 215.9 & 74.1 & 57.5 & 0 & 42.2 & 0 & 6.2 & 395.9 \\
\hline \multicolumn{10}{|c|}{ Operational Cost : } \\
\hline Feeding cost & - & $10,793,250$ & $14,614,647$ & $7,660,800$ & & $7,920,000$ & 7,440 & 809,550 & $41,805,687$ \\
\hline Labor cost & - & $13,431,600$ & $46,436,234$ & $9,336,600$ & & $6,336,000$ & 15,792 & 771,000 & $76,327,226$ \\
\hline $\begin{array}{l}\text { Maintenance } \\
\text { cost }\end{array}$ & - & $6,715,800$ & $19,449,150$ & $16,566,480$ & & $12,179,200$ & 7,800 & 648,873 & $55,567,303$ \\
\hline $\begin{array}{l}\text { Total } \\
\text { Expenditures }\end{array}$ & & & & & & & & & $173,700,217$ \\
\hline Balance & & & & & & & & & $662,253,507$ \\
\hline
\end{tabular}


needed socialization to the surrounding societies to develop deer with multi-functions, determining the government regulation about deer raising, publish the tourism places, and so on. To expand the agricultural commodities, market segmentation of commercial Timor deer was needed.

Protein resource diversification by cultivating the specific wildlife with considering reservation principle is a good and logical method to maintain the exploitation balance and potential natural resources. So, deer breeding can be a new advantage alternative in supplying and diversifying new protein resources (Puttoo, 1998), considering that deer has high environmental adaptation, simple reproduction and feeding supply as well as the natural condition in East Java are really supporting the natural habitat of timor deer (Santoso et al., 2006).

In order to gain maximum profit from Timor deer development, breeders must understand the regulation policies required for developing deer through multi-functions, such as: (a) expanding areas, (b) socializing to societies about deer development by using multi-functions, (c) determining the government regulations regarding on deer breeding, and (d) publishing tourism places.

Nevertheless, it also needs a support from infrastructure which currently becomes the major barrier in order to have a deeply consideration from our government, to change the society opinion about cultivating deer in Indonesia. Timor deer can be an agricultural commodity asset which is openly marketed in national meat markets, such as beef, goat and sheep meat. Hence, the commercial deer development will maximize the profit for breeders. From economic perspective, the product of deer breeding can be marketed, open an opportunity to export, maximizing the available resources, and saving national currency in long-term.

\section{CONCLUSIONS}

Developing Timor deer in commercial purpose had benefit from selling velvet, antler, live deer, recreation tickets, and it was capable to reduce costs to pay labors and deer caring cost for 18 months harvesting period. The breeding of Timor deer by commercial purpose showed positive effect. To reserve Timor deer, it could be done by the conservation as well as commercial purpose. The benefit obtained by commercial purpose was IDR 100 from every IDR 1 of investment in Timor deer commercialization. Developing of deer to prevent the extinct animal can be conducted by multi-functions, namely the combination of conservation and commercial efforts. In the future, conservation of deer in recreation place not only for financial benefit, but also for larger economic advantages, such as labor recruitment from the surrounding location, recreation, and profit from selling some potential deer commodities.

\section{REFERENCES}

Bromley, C and E. M. Gese. 2001. Effects of sterilization on territory fidelity and maintenance, pair bonds, and survival rates of free-ranging coyote. Can. J. Zoology. 79:386-392

Chuang, TH. and Y.C. Lu. 1997. Application of multiple-goal programming and AHP in course scheduling. Department of Industrial Engineering and System Management, Chung Hua University, Hsinchu, Taiwan

Dradjat, A.S. 2002. Hasil Penelitian Biologi Rusa Indonesia dalam kaitnnya dengan pengembangan sebagai hewan ternak dalam : Strategi dalam pemanfaatan \& pengembangan ternak rusa sebagai ternak alternative penghasil daging dan hasil ikutannya yang bernilai tinggi. Workshop. Dirjen Bina Produksi Peternakan. Jakarta, 10 September 2002.

Fatem, S.M. 2002. Rusa (Cervus timorensis) dan Prospek Pengembangannya di Papua. Prosiding Seminar Nasional Bioekologi dan Konservasi Ungulata. Pusat Studi Ilmu Hayati, Lembaga Penelitian IPB.

Garsetiasih, R. 2000. Bioekologi Rusa Timor dan Peluang Pengembangan Budidayanya. Buletin Kehutanan dan Perkebunan. 1(1):2132.

Jamal, Y., G. Semiadi and M. Hamsun, M. 2005. Nilai gizi daging rusa Timor (Cervus Timorensis) hasil perburuan. J. Produksi Ternak. 7(1): 46-51.

Puttoo, M.. 1998. Performance of Weaned Rusa (Cervus Timorensis) deer given concentrates of varying protein content with soranghum hay. Aust. J. Exp. Agric. 38:33-39

Santoso, I.S., G. Semiadi and S. Pudiatmoko. 2006. Evaluasi Penangkaran Rusa di Pulau Jawa. National Seminar on Innovative 
Technology Development to Support a Constant Animal Agricultural Development. Faculty of Animal Science, Jenderal Soedirman University, Purwokerto, 11 Februari 2006.

Schuhmann, P.W. and K.A. Schwabe. 2000. The Welfare Implications of Alternative Deer Management Strategies: A Dynamic Exercise in Using the Nested Multinomial Logit Model. Presented at the annual meetings of the Western Agricultural Economics Association. June 29-1 July, 2000. Vancouver. British Columbia. Canada. Semiadi, G. dan R.T.P. Nugraha. 2004. Panduan Pemeliharaan Rusa Tropis. LIPI Biological Research Center, Bogor.

Soekartawi. 1995. Multi Objective Goal Programming (MOGP): Programasi Tujuan Ganda, Teori dan Aplikasinya. PT.Grasindo. Jakarta 